\title{
PREVALENCE ASYMPTOMATIC URINARY TRACT INFECTION IN SCHOOL AGE BOYS BASED ON DIPSTICK TEST AND SEDIMENT MICROSCOPY
}

\author{
Miftahurrahmah dan Mirna Marhami Iskandar \\ Universitas Jambi, Indonesia \\ Email:miftahurrahman_fkik@unja.ac.id dan mirnaiskandar@gmail.com
}

\begin{abstract}
Urinary tract infection is one of the most infection desease. Rapid screaning with urine dipstick and microscopy sediment are helpful to early detection urinary tract infection. The purpose of this study to identification urinary tract infection in school age boys who underwent circumcision and not. this is a cross sectional study, the sample are boys in elementary school without urinary tract infection sign who underwent circumcision and not. the criteria presumptive UTI based on dipstick who had positive nitrit or positive leukocyte esterase. The criteria presumptive UTI based on sediment urinalysis who had WBC more than 3 or positive bacteria. there are 126 boys with mean age 8.3 years old (6-12 years old). There are 90(71\%) boys underwent circumcision and 36(29\%) boys not circumcision. presumtive UTI based on dipstick only one (0.8\%) boy underwent circumcised. Presumptive UTI based on sediment urinalysis are 50(40\%) boys consist of 32 (36\%) boys underwent circumcision and $18(50 \%)$ boys without circumcission.
\end{abstract}

Keywords: UTI; urinalysis; circumcised

\begin{abstract}
Infeksi saluran kemih (ISK) merupakan salah satu penyakit infeksi yang sering terjadi. Skrining cepat dengang menggunakan uji dipstick dan sedimen mikroskopis dapat membantu dalam deteksi infeksi saluran kemih. Penelitian ini bertujuan melakukan identifikasi infeksi saluran kemih pada anak usia sekolah yang telah dilakukan sirkumsisi dan belum sirkumsisi. Penelitian ini merupakan study cross sectional, sample pada penelitian ini adalah anak laki-laki usia sekolah yang telah dilakukan sirkumsisi dan belum dilakukan sirkumsisi. Adapun kriteria ISK berdasarkan uji dipstick adalah memiliki nitrit positif atau leukosit esterase positif, sedangkan kriteria sedimen mikroskopis berupa WBC lebih dari 3 atau bakteri positif. Terdapat 126 anak laki-laki dengan rerata usia 8.3 tahun (6-12 tahun). Sekitar 90 (71\%) orang anak laki-laki yang telah dilakukan sirkumsisi dan sekitar 36 (29\%) orang anak laki-laki yang belum sirkumsisi ISK berdasarkan uji dipstick ditemukan hanya $1(0.8 \%)$ orang anak laki-laki yang telah sirkumsisi, sedangkan sedimen mikroskopis $50(40 \%)$ orang anak laki-laki yang terdiri dari $32(36 \%)$ anak laki-laki yang telah dilakukan sirkumsisi dan 18 (50\%) anak laki-laki yang tidak dilakukan sirkumsisi.
\end{abstract}

Kata Kunci: UTI; urinalysis; circumcised 


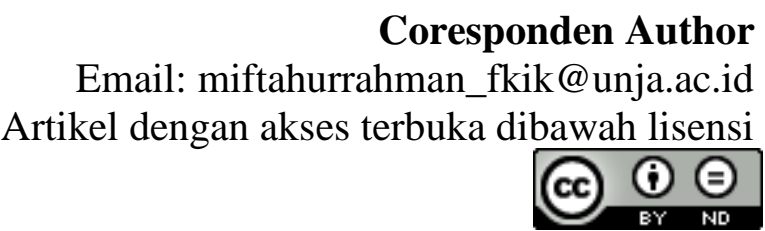

\section{Pendahuluan}

Infeksi Saluran Kemih (ISK) adalah istilah umum yang dipakai untuk menyatakan adanya invasi mikroorganisme pada saluran kemih (Purnomo, 2003). ISK salah satu penyakit yang paling sering ditemukan di masyarakat termasuk di negara maju (Gusrianty, Hartinah, \& Susanti, 2015). Infeksi ini ditemukan di RS yang mengakibatkan angka morbiditas dan mortalitas yang signifikan (Sumolang, Porotu'o, \& Soeliongan, 2013). Sejalan dengan pendapat (Barratt \& Topham, 2009) ISK adalah sebuah kondisi medis umum yang mengakibatkan angka morbiditas dan mortalitas yang signifikan.

ISK merupakan penyakit infeksi yang sering terjadi pada anak-anak di Amerika Serikat dengan kejadian 70.000 sampai 180.000 orang menderita infeksi saluran kemih (Habib, 2012). Insiden ISK ini pada bayi dan anak sekolah berkisar 1-2\% (Arslan et al., 2002). Prevalensi penyakit ini di turki pada anak usia sekolah perempuan $7.8 \%$ sedangkan laki-laki 1.6\% (Zincir et al., 2012). Bakteriuria asimptomatik ditemukan pada kurang dari $1 \%$ bayi cukup bulan, $3 \%$ anak usia sekolah dan $1 \%$ pada anak yang lebih tua (Stein et al., 2015). Namun, kondisi dengan bakteriuria dan leukosituria yang bermakna dapat disertai tanpa gejala (Schmidt \& Copp, 2015). Kebanyakan kasus seperti ini ditemukan di negara yang jarang melakukan sirkumsisi (Shaikh, Osio, Wessel, \& Jeong, 2020).

Kondisi umum yang mempengaruhi meningkatnya angka kejadian infeksi saluran kemih pada anak usia sekolah berupa fasilitas sekolah yang kurang bersih, kurangnya kebiasaan hidup bersih, kebiasaan mencuci area perineum dan genital yang salah, cairan yang masuk tidak adekuat. 2 Hal ini mengakibatkan terjadinya ascending infection dengan jenis bakteri yang paling banyak ditemukan berupa gram negative seperti Escherichia coli (Leung, Kao, \& Robson, 2005).

Adapun keterlambatan dalam menegakkan diagnosis dapat mengakibatkan terjadinya renal scaring sedangkan berlebihan dalam mendiagnosis menyebabkan anak akan menjalani paparan radiasi, pengobatan, dan peningkatan biaya (Robinson et al., 2014). Leukosit esterase, nitrit, dan pemeriksaan mikroskopis dilakukan secara bersamaan memiliki sensitivitas $99 \%$ sedangkan pemeriksaan nitrit memiliki spesifitas 98\% dalam mendiagnosis infeksi saluran kemih (Dahiya \& Goldman, 2018). Oleh sebab itu Penelitian ini bertujuan melakukan identifikasi infeksi saluran kemih pada anak usia sekolah yang telah dilakukan sirkumsisi dan belum sirkumsisi.

\section{Metode Penelitian}

Penelitian ini merupakan study cross sectional secara deskriptif. Sample pada penelitian ini adalah anak laki-laki usia sekolah baik yang telah dilakukan sirkumsisi 
dan belum dilakukan sirkumsisi di SD Negeri 44 kecamatan Pelayangan. Adapun pengambilan urin yang dilakukan menggunakan uji midstrim kemudian dilakukan pemeriksaan dipstick urin dan mikroskopis urin di laboratorium biomedik FKIK Universitas Jambi. Selain daripada itu dilakukan juga penilaian mengenai faktor-faktor yang dapat meningkatkan resiko terjadinya infeksi saluran kemih seperti kebiasaan menahan buang air kecil, kebiasaan kurang suka minum air putih, kebiasaan mengenai kebersihan area genitalia setelah buang air kecil dan buang air besar.

Adapun kriteria praduga ISK berdasarkan dipstick dan mikroskopis. Pemeriksaan mikroskopis digunakan untuk mendeteksi pyuria (WBC di urin tiga atau lebih perlapangan pandang) dan atau bakteriuria. Pemeriksaan dipstick berdasarkan Nitrit dan atau leukosit esterase (Lee, 2015).

Tabel 1

Prediksi Diagnosis Berdasarkan Pemeriksaan Dipsitik

\begin{tabular}{ll}
\hline Dipstick urin & ISK \\
\hline Nitrit (+), LE(+) & Bisa jadi \\
\hline Nitrit (+), LE(-) & Mungkin \\
\hline Nitrit (-), LE(+) & $+/-$ \\
\hline Nitrit (-), LE(-) & - \\
\hline
\end{tabular}

\section{Hasil dan Pembahasan}

\section{A. Hasil Penelitian}

Kegiatan penelitian ini telah dilaksanakan selama tiga hari pada tanggal 16-17 September 2020 dan pada tanggal 22 September 2020 di SD Negeri 44 Kecamatan Pelayangan yang merupakan salah satu sekolah dasar di wilayah kerja puskesmas Tahtulyaman. Kegiatan ini dalam pelaksanaannya melibatkan mahasiswa FKIK Universitas Jambi kegiatan penelitian ini dilakukan dengan pengambilan urin midstrim pada anak dengan dibantu oleh mahasiswa yang dilibatkan dalam kegiatan ini. Setelah dilakukan pengambilan urin maka dilakukan pemeriksaan dipstick urin dan mikroskopis urin di laboratorium biomedik FKIK Universitas Jambi. Selain pemeriksaan urin dipstick, dilakukan juga penilaian mengenai faktor-faktor yang dapat meningkatkan resiko terjadinya infeksi saluran kemih seperti sirkumsisi, kebiasaan menahan buang air kecil, kebiasaan kurang suka minum air putih, kebiasaan mengenai kebersihan area genitalia setelah buang air kecil dan buang air besar.

Jumlah siswa laki-laki di sekolah tersebut 161 siswa, namun yang bersedia ikut serta dalam pengabdian ini sebanyak 126 siswa laki-laki. Adapun sebaran usia siswa dalam pengabdian ini berkisar dari 6 tahun - 12 tahun, dengan rerata usia 8.3 tahun. 
Tabel 2

Sebaran Usia

\begin{tabular}{lcc}
\hline \multicolumn{1}{c}{ Usia } & Frekuensi & \% \\
\hline 6 tahun & 21 & 16,7 \\
\hline 7 tahun & 26 & 20,6 \\
\hline 8 tahun & 25 & 19,8 \\
\hline 9 tahun & 18 & 14,3 \\
\hline 10 tahun & 19 & 15,1 \\
\hline 11 tahun & 15 & 11,9 \\
\hline 12 tahun & 2 & 1,6 \\
\hline
\end{tabular}

Pemeriksaan urin dilakukan kepada semua siswa yang bersedia yaitu sebanyak 126 siswa. pemeriksaan urin dipstick dengan.

Pemeriksaan Urin

\begin{tabular}{|c|c|c|c|c|}
\hline Urinalisis & $\begin{array}{c}\text { Post } \\
\text { sirkumsisi }\end{array}$ & $\%$ & $\begin{array}{c}\text { Pre } \\
\text { sirkumsisi }\end{array}$ & $\%$ \\
\hline \multicolumn{5}{|l|}{ Dipstik } \\
\hline \multicolumn{5}{|l|}{ Nitrit } \\
\hline Positif & 1 & 1 & 0 & 0 \\
\hline Negatif & 89 & 99 & 36 & 100 \\
\hline \multicolumn{5}{|l|}{$\mathbf{L E}$} \\
\hline Positif & 0 & 0 & 0 & 0 \\
\hline Negatif & 90 & 100 & 36 & 100 \\
\hline \multicolumn{5}{|l|}{ Mikroskopis } \\
\hline \multicolumn{5}{|l|}{ Leukosit } \\
\hline $0-1$ & 83 & 92 & 34 & 94 \\
\hline $0-2$ & 6 & 7 & 2 & 6 \\
\hline $0-3$ & 1 & 1 & 0 & 0 \\
\hline \multicolumn{5}{|l|}{ Bakteri } \\
\hline Positif & 32 & 36 & 18 & 50 \\
\hline Negatif & 58 & 64 & 18 & 50 \\
\hline
\end{tabular}

Melakukan penilaian nitrit dan leukosit esterase sebagai penanda infeksi saluran kemih. Seluruh urin yang di lakukan pemeriksaan secara makroskopis tampak jernih, warna kuning, tidak terdapat grosss hematuria. Pada pemeriksaan dipstick ditemukan satu siswa yang memberikan hasil nitrit positif pada kelompok sirkumsisi dan tidak ada yang memiliki leukosit esterase positif. Pada pemeriksaan mikroskopis urin didapatkan bakteri positif sebanyak 32 (36\%) siswa post sirkumsisi dan 18 (50\%) siswa presirkumsisi. Namun, pada pemeriksaan urin semua sample memiliki kristal urin.

Pemeriksaan dipstick urin dan mikroskopis dapat digunakan sebagai prediksi dalam penegakan diagnostic dan penatalaksanaan berdasarkan nilai nitrit dan leukosit esterase. Pada penelitian ini berdasarkan pemeriksaan dipstick ditemukan satu siswa diprediksikan mendarita infeksi saluran kemih asimptomatik, kondisi ini berdasarkan hasil dipstick berupa positif nitrit. 
Tabel 4

Prediksi Diagnosis infeksi saluran kemih Berdasarkan Pemeriksaan Dipsitik

\begin{tabular}{llcccc}
\hline $\begin{array}{l}\text { Dipstick } \\
\text { Urin }\end{array}$ & ISK & Post sirkumsisi & $\%$ & Pre sirkumsisi & $\%$ \\
\hline $\begin{array}{l}\text { Nitrit (+), } \\
\text { LE(+) }\end{array}$ & Bisa jadi & 0 & 0 & 0 & 0 \\
\hline $\begin{array}{l}\text { Nitrit (+), } \\
\text { LE(-) }\end{array}$ & Mungkin & 1 & 1 & 0 & 0 \\
\hline $\begin{array}{l}\text { Nitrit (-) } \\
\text { LE(+) }\end{array}$ & $+/-$ & 0 & 0 & 0 & 0 \\
\hline $\begin{array}{l}\text { Nitrit (-) } \\
, \text { LE(-) }\end{array}$ & - & 89 & 99 & 36 & 100 \\
\hline
\end{tabular}

Pada pemeriksaan mikroskopis prediksi ISK sebanyak 32 siswa (36\%) pada kelompok post sirkumsisi dengan bakteriuria dan tidak memiliki pyuria sedangkan kelompok presirkumsisi sebanyak 18 siswa (50\%).

Tabel 5

Prediksi Diagnosis infeksi saluran kemih Berdasarkan Pemeriksaan mikroskopis

\begin{tabular}{llllll}
\hline $\begin{array}{l}\text { Mikroskopis } \\
\text { Urin }\end{array}$ & Isk & $\begin{array}{l}\text { Post } \\
\text { sirkum }\end{array}$ & $\begin{array}{l}\text { Pre } \\
\text { sirkum }\end{array}$ & \% \\
\hline $\begin{array}{l}\text { Leukosit(+), bakteri } \\
(+)\end{array}$ & Bisa jadi & 0 & 0 & 0 & 0 \\
\hline $\begin{array}{l}\text { Leukosit (-) } \\
\text { Bakteri (+) }\end{array}$ & Mungkin & 32 & 36 & 18 & 50 \\
\hline Leukosit(+), bakteri (-) & $+/-$ & 0 & 0 & 0 & 0 \\
\hline Leukosit(-), bakteri (-) & - & 58 & 64 & 18 & 50 \\
\hline
\end{tabular}

Pada penelitian ini selain kami melakukan deteksi dini infeksi saluran kemih secara cepat dan mudah, kami juga mentelaah kemungkinan faktor-faktor lain yang dapat meningkatkan angka kejadian infeksi saluran kemih pada anak usia sekolah. Antara lain kebiasaan menahan BAK, membersihkan genitalia, cuci tangan dan minum air. Pada penelitian ini baik kelompok post sirkum dan presirkum yang terduga ISK memiliki kebiasan hidup bersih yang baik. Hal ini ditunjukkan dengan kebiasaan mencuci tangan pada kelompok post sirkum sebanyak $84 \%$ dan presirkum sebanyak $100 \%$ serta Kebiasaan membersihkan genitalia dengan baik dengan persentase $81 \%$ post sirkum dan $100 \%$ presirkum. Namun, baik kelompok presirkum maupun post sirkum memiliki kebiasaan kurang baik berupa menahan BAK dan intake cairan yang tidak adekuat. Kondisi ini ditunjukkan dengan kebiasaan menahan BAK pada kelompok pre sirkum maupun post sirkum sebanyak $50 \%$ dan kebiasaan intake cairan yang tidak adekuat pada kelompok presirkum sebanyak $44 \%$ sedangkan post sirkum sebanyak $78 \%$. 


\section{B. Pembahasan}

Kavitha J, dkk dalam penelitian prospektif didapatkan tidak dilakukan sirkumsisi merupakan salah satu faktor yang menyebabkan terjadinya infeksi saluran kemih sebanyak 86.7\% (Kavitha, Aravind, Jayachandran, \& Priya, 2017). Pada skrining yang dilakukan ini, dikarenakan besar siswa telah dilakukan sirkumsisi dan didapatkan angka kemungkinan infeksi saluran kemih berdasarkan mikroskopis urin sebesar $36 \%$, namun pada siswa yang presirkumsisi sebesar $50 \%$.

\section{Table 6}

Faktor Resiko Infeksi Saluran Kemih pada siswa terduga ISK

\begin{tabular}{ccccc}
\hline Faktor resiko & $\begin{array}{c}\text { Post } \\
\text { sirkum }\end{array}$ & \% & Pre sirkum & \% \\
\hline Menahan BAK & & & & \\
\hline Ya & 16 & 50 & 9 & 50 \\
\hline Tidak & 16 & 50 & 9 & 50 \\
\hline Membersihkan Genitalia & & & & \\
\hline Ya & 25 & 78 & 18 & 100 \\
\hline Tidak & 7 & 22 & 0 & 0 \\
\hline Cuci Tangan & 30 & 94 & 18 & 100 \\
\hline Ya & 2 & 6 & 0 & 0 \\
\hline Tidak & & & & \\
\hline Minum Air & 24 & 75 & 8 & 44 \\
\hline$<8$ gelas & 8 & 25 & 10 & 56 \\
\hline
\end{tabular}

(Zincir et al., 2012) menyatakan bahwa anak yang minum air tidak adekuat dan memiliki riwayat keluarga menderita infeksi saluran kemih memiliki prevalensi tinggi terhadap kejadian infeksi saluran kemih, selain dari pada itu kebiasaan mencuci tangan setelah dari toilet dan mencuci daerah genitalia memiliki hubungan yang bermakna terhadap kejadian infeksi saluran kemih. Adapun penelitian lainnya berupa penelitian prospektif yang dilakukan oleh Kavitha dkk bahwa minum yang tidak adekuat dapat mengakibatkan infeksi saluran kemih sebanyak 34.6\%. Pada penelitian ini ditemukan kebiasaan minum yang tidak adekuat baik kelompok presirkumsisi dan post sirkumsisi dengan terduga ISK sangat tinggi yaitu $78 \%$ pada kelompok post sirkumsisi dan $44 \%$ pada kelompok presirkumsisi. Kebiasaan mencuci area genitalia dan mencuci tangan merupakan kebiasaan yang telah dilakukan oleh Seluruh siswa terduga ISK pada kelompok presirkumsisi (100\%) sedangkan pada kelompok post sirkumsisi $81 \%$ siswa mencuci tangan dan $84 \%$ siswa membersihkan genitalia (Kavitha et al., 2017).

Berdasarkan penelitian yang menyatakan bahwa jika terdapat bacteriuria namun tanpa disertai dengan gejala klinis maka sebaiknya dilakukan evaluasi hal ini 
dikarenakan kejadian infeksi saluran kemih dengan bacteriuria positif tanpa disertai demam sedikit sekali (Shaikh et al., 2020). Oleh sebab itu peneliti menganjurkan siswa yang terduga infeksi saluran kemih sebaiknya dilakukan evaluasi kembali dan diberikan edukasi tentang perilaku hidup bersih dan sehat serta menghindari kebiasaan buruk menahan BAK serta mencukupi asupan cairan perhari.

\section{Kesimpulan}

Dari penelitian yang telah dilakukan ditemukan bahwa prevalensi infeksi saluran kemih asimptomatik pada anak laki-laki usia sekolah yang presirkumsisi lebih banyak bila dibandingkan dengan post sirkumsisi. Faktor-faktor lain yang dapat meningkatkan angka kejadian infeksi saluran kemih pada anak usia sekolah yaitu kebiasaan menahan BAK, membersihkan genitalia, cuci tangan dan minum air.

Kelompok post sirkum dan presirkum yang terduga ISK memiliki kebiasan hidup bersih yang baik. Hal ini ditunjukkan dengan kebiasaan mencuci tangan pada kelompok post sirkum sebanyak $84 \%$ dan presirkum sebanyak $100 \%$ serta Kebiasaan membersihkan genitalia dengan baik dengan persentase $81 \%$ post sirkum dan $100 \%$ presirkum. Namun, kelompok presirkum maupun post sirkum juga memiliki kebiasaan kurang baik berupa menahan BAK dan intake cairan yang tidak adekuat. Kondisi ini ditunjukkan dengan kebiasaan menahan BAK pada kelompok pre sirkum maupun post sirkum sebanyak $50 \%$ dan kebiasaan intake cairan yang tidak adekuat pada kelompok presirkum sebanyak $44 \%$ sedangkan post sirkum sebanyak $78 \%$. 


\section{BIBLIOGRAFI}

Arslan, Sükrü, Caksen, Hüseyin, Rastgeldi, Levent, Uner, Abdurrahman, Oner, Ahmet Faik, \& Odabaş, Dursun. (2002). Use of urinary gram stain for detection of urinary tract infection in childhood. The Yale Journal of Biology and Medicine, 75(2), 73.

Barratt, Jonathan, \& Topham, Peter. (2009). Oxford Desk Reference: Nephrology. Oxford Medical Publications.

Dahiya, Anita, \& Goldman, Ran D. (2018). Management of asymptomatic bacteriuria in children. Canadian Family Physician, 64(11), 821-824.

Gusrianty, Alvie Rizky, Hartinah, Hartinah, \& Susanti, Ari Indra. (2015). Angka Kejadian Gejala Infeksi Saluran Kemih pada Ibu Hamil di Desa Mekargalih Kecamatan Jatinangor Kabupaten Sumedang Tahun 2014. Jurnal Sistem Kesehatan, 1(2).

Habib, Sabeen. (2012). Highlights for management of a child with a urinary tract infection. International Journal of Pediatrics, 2012.

Kavitha, J., Aravind, M. A., Jayachandran, G., \& Priya, S. (2017). Risk factors for urinary tract infection in pediatric patients. International Journal of Contemporary Pediatrics, 5(1), 184-189.

Lee, Seung Joo. (2015). Clinical guideline for childhood urinary tract infection (second revision). Childhood Kidney Diseases, 19(2), 56-64.

Leung, Alexander K. C., Kao, C. Pion, \& Robson, William Lane M. (2005). Urinary tract infection due to Salmonella stanleyville in an otherwise healthy child. Journal of the National Medical Association, 97(2), 281.

Purnomo, B. (2003). Dasar-dasar Urology (2nd editio). Jakarta.

Robinson, Joan L., Finlay, Jane C., Lang, Mia Eileen, Bortolussi, Robert, Society, Canadian Paediatric, Committee, Community Paediatrics, \& Committee, Infectious Diseases and Immunization. (2014). Urinary tract infection in infants and children: Diagnosis and management. Paediatrics \& Child Health, 19(6), 315-319.

Schmidt, Bogdana, \& Copp, Hillary L. (2015). Work-up of pediatric urinary tract infection. Urologic Clinics, 42(4), 519-526.

Shaikh, Nader, Osio, Victor A., Wessel, Charles B., \& Jeong, Jong H. (2020). Prevalence of asymptomatic bacteriuria in children: a meta-analysis. The Journal of Pediatrics, 217, 110-117.

Stein, Raimund, Dogan, Hasan S., Hoebeke, Piet, Kočvara, Radim, Nijman, Rien J. M., Radmayr, Christian, \& Tekgül, Serdar. (2015). Urinary tract infections in children: EAU/ESPU guidelines. European Urology, 67(3), 546-558. 
Miftahurrahmah dan Mirna Marhami Iskandar

Sumolang, Shirby A. Ch, Porotu'o, John, \& Soeliongan, Standy. (2013). Pola bakteri pada penderita infeksi saluran kemih di blu RSUP Prof. Dr. RD Kandou Manado. EBiomedik, 1(1).

Zincir, Handan, Erten, Zeliha Kaya, Özkan, Filiz, Seviğ, Ümit, Başer, Mürüvvet, \& Elmal1, Ferhan. (2012). Prevalence of urinary tract infections and its risk factors in elementary school students. Urologia Internationalis, 88(2), 194-197. 